\title{
Effect of Work-Family Conflict and Job Satisfaction on Quality of Work Life
}

\author{
OWOLABI Ademola Benjamin \\ Department Of Psychology \\ Ekiti State University, Ado-Ekiti
}

\begin{abstract}
This study attempted to investigate the effect of work-family conflict and job satisfaction on quality of work life. Data were obtained from two hundred (200) respondents in which one hundred and eighty-nine was found valid for analysis. The respondent used consists of (100) female workers and (89) male workers both in the public and private sectors, respondents reside and work in Ado-Ekiti. Three instruments were used in this study to measure work-family conflict, job satisfaction and quality of work life. Three hypotheses were tested. This study shows that there is a significant effect of work-family conflict and job satisfaction on quality of work life, but there are no significant sex differences in work-family conflict, job satisfaction and quality of work life.
\end{abstract}

Key words: Quality of work life, Job satisfaction, Work - family conflict, Organisation

\section{INTRODUCTION}

A high quality of work life is essential for organizations to continue to attract and retain employees. Sometimes abbreviated QWL, quality of work life is quick phrase that encompasses a lot, because it refers to the thing an employer does that adds to the lives of employees. Those "things" are some combination of benefits explicit and implied, tangible and intangible that make somewhere good place to work and another a bad place to work. In an organization, a high level of quality of work life is necessary to continue to attract and retain employees. Rethinam and Ismai (2006), reviewed different researches about meanings and constructs of quality of work life and designated that quality of work life is a multi-dimensional construct and is made of a number of inter-related factors. Quality of work life is a set of principles which holds that people are the most important resource in the organisation as they are trustworthy, responsible and capable of making valuable contribution and they should be treated with dignity and respect (Straw and Heckscher, 1984). Quality of work life entails the design of work systems that enhance the working life experiences of organizational members, thereby improving commitment to and motivation for achieving organizational goals.

Organizations are continuously looking for new ways of doing business in order to meet the challenges of today's dynamic business environment. Given the amount of time and energy people expend at the workplace, it is important for employees to be satisfied about their life at work. Glass \& Finley, (2002), Van der Lippe, (2007) argued that time pressure is a serious problem in today's workforce, with ever-increasing numbers of workers bearing major responsibilities at home and meeting higher job expectations and heavier demands at work. A mismatch between family and work roles can be disadvantageous for both employees and employers. In fact as early as 1960's researchers had begun to study and connect the dots between work and family. Numerous researcher such as Greenhaus and Powell, (2006), Owolabi and Babalola (2014) demonstrate that what happened in the workplace have significant impact on individuals and their families. Researchers have shown that the combination of a fluctuating work environment with competing job and family commitments 
has negatively affect employees in the form of lowered morale and motivation, reduced productivity, and increased burnout and turnover. Moreover the inability of employee to balance the equally challenging demands of their work and personal life has contributed to the escalating stress and conflict of today's workforce, this in turn leads to significant rise in stress related health problem, which translates to financial cost both to the employer as well as the government.

These days, for an organization to be successful and achieve its organizational objectives it is imperative that its employees are satisfied with their work, since work occupies an important place in many people's lives, such conditions are likely to affect not only their physical but also a high level of social, psychological and spiritual well-being. It is well established in various researches that employees with a high level of psychological well-being are better, more committed, and more productive than employees with a low level of psychological well-being. Nonetheless, Chan and Wyatt 2007, Srivastava (2007) suggest that employees are likely to have higher wellbeing if they are satisfied with their work and organization and they perceive their quality of work life positively, since an employee's experiences in the workplace and his/her quality of work life influence his/her health and psychological well-being.

The success of any organization is highly dependent on how it attracts recruits, motivates, and retains its workforce. In the search for improved productivity, manager and executives alike are discovering the important contribution of quality of work life. The evolution of quality of work life began in late 1960s where, during this time the focus was on the quality of the relationship between the worker and the working environment.

A review of literature according to Chandrashu (2012) shows that there are twelve important factors that enhance the quality of employee work life especially when the management of an organisation works towards the development of organization's most valuable assets (employees). The factors include the following: effective and efficient communication system, opportunity for career development and personal growth, organizational committed and emotional supportive supervisor, flexible work arrangement that permit employee to have time for personal issues, a responsive family culture, a highly design employee motivation system, supportive organizational climate, organizational support system, job satisfaction; adequate rewards and benefits system and compensation.

\section{Job Satisfaction}

Research indicates that employee satisfaction is important to an organisation's success. Job satisfaction is a widely studied construct in organisational behaviour as it influences other organisational variables like productivity, turnover and absenteeism. Atchison (1999) states that many organisations are spending much time on employee satisfaction initiatives in an effort to reduce turnover, improve productivity and to help organisations succeed. Hoole and Vermeulen (2003) maintain that the popularity of this field of study is also due to its relevance to the physical and mental well-being of employees. Furthermore, Robbins (2005) postulates that managers have a humanistic responsibility to provide employees with jobs that are challenging, rewarding and satisfying. According to Alavi and Askaripur (2003), there are at least three reasons why managers must focus on the job satisfaction of its employees;

- Evidence suggests that unsatisfied individuals leave organisations.

- Satisfied employees are in better health and have longer life expectancy. Connolly and Myers (2003) further maintain that a lack of job satisfaction has been associated with symptoms like anxiety, depression and poor physical and psychological health, which have concomitant consequences for absenteeism and commitment. 
- Job satisfaction in the workplace also affects individuals' private lives which in turn has an effect on absenteeism and other important work-related attitudes and behaviour.

Rhodes \& Steers (1990) list seven factors related to the job situation that could lead to increased job satisfaction, namely, job scope, job level, role stress, size of the work group, style of the leader, co-worker relations and the opportunity for advancement .Job satisfaction is a complex variable and is influenced by factors of the job environment as well as dispositional characteristics of an individual. These factors have been arranged according to two dimensions, namely, extrinsic and intrinsic factors (Buitendach \& De Witte 2005). The extrinsic factors include things like pay, promotion opportunities, co-workers, supervision and recognition. Intrinsic factors include personality, education, intelligence and abilities, age and marital status (Mullins, 1999). Extrinsic sources of job satisfaction are determined by conditions that are beyond the control of the employee (Atchison, 1999). The following have been discovered to affect job satisfaction namely, pay, the job itself, promotion opportunities, supervision, co-workers, working conditions and the issue of fairness

\section{Work family conflict}

Managing the conflict between family and work obligations is an important issue. The demands of family and work pose critical challenges to individuals, researchers, and organisations. In Malaysia, the percentage of women in tertiary education and, consequently, in professional roles has been rising steadily. In 1990, 45.7\% of women were in tertiary education (Department of Statistics, Malaysia 1992) compared with 38.6\% in 1980 (Department of Statistics, Malaysia 1983). Of the economically active population, $10.7 \%$ of women were in professional, technical and related occupations in 1992 (Department of Statistics, Malaysia 1994) compared with 4.8\% in 1970 (Department of Statistics, Malaysia 1972).With these changing demographics; women have to deal with job-related demands which place limits on the performance of their family role. This trend results in work-family conflict as women try to cope with conflicting demands of work and the family (Aminah 1995). In Nigeria, men have traditionally played the role of breadwinner in the family while the women stay back to take care of the home front with little or no formal job but things have change drastically with more women become career person just like their husband. To Aryee (1999), the increased participation of married women in the labor force in the US and other industrialized countries has led to a growing realization that the work and family domains are highly interdependent. He observes that adults in dual earner and single parent households must constantly strive to balance work and family requirements.

The growing number of dual career couples and working mothers with young children has made it more likely that both men and women have both family and work obligations. With the shifts in family and work domains, individuals must face and adapt to the inter-role conflict (Frone and Rice, 1987). Family-work conflict is a source of pressure, and can cause problems with health, work performance, hereby affecting the quality of work life of the individual involved. According to Greenhaus \& Beutel in 1985, these changes have led to considerable scholarship on work and families, including research on work-family conflict. Family-work conflict has been associated with a number of dysfunctional outcomes (Bacharach, Bamberger, \& Conley, 1990), decreased family and occupational well-being (Kinnunen and Mauno,1998), and job and life dissatisfaction (Netermeyer, Boles,\& McMurrian, 1996). Netermeyer, et al (1996) observes that work and family are two important domains that are not compatible and that there are usually conflicts between the two domains. The domain flexibility hypothesis predicts that the work domain is a greater source of conflict than the family domain for both men and women. The domain salience hypothesis predicts that the family domain is a greater source of conflict for women and the work domain a greater source of conflict for men (Izraeli 1988). 
Research shows that participation in one role is made more difficult by virtue of participation in the other (Greenhaus \& Beutel, 1985). Conflict between work and family is important for organizations and individuals because it is linked to negative consequences. For example, conflict between work and family is associated with increased absenteeism, increased turnover, decreased performance, and poorer physical and mental health. Researchers make the distinction between what is termed work-family conflict, and what is termed family-work conflict. Work-to-family conflict occurs when experiences at work interfere with family life, like extensive, irregular, or inflexible work hours, work overload and other forms of job stress, interpersonal conflict at work, extensive travel, career transitions, unsupportive supervisor or organization. For example, working long hours may prevent adequate performance of family responsibilities. Family demands may also interfere with work, e.g., a child's illness may prevent attendance at work or school. Understanding the points of view and interpreting the emotional state and behavior of others depend on the ability to deal with the emotions aroused by social interaction, and are developed from information use (Welsh and Bierman, 2002).

Voydanoff (1988) posits that meeting the often incompatible demands of family and work may create family-work conflict. Dorren (2009) discovered that long work hours and the relative absence of organizational family life combine to create conflict between family responsibilities and work school with particular reference to the married male and female postgraduate students in the Faculty of Education, University Ibadan. The researcher has observed signs of worry and stress among students, especially the working parents. Some are not regular in class attendance; some even come to the lecture-room with babies, assignments were not done and submitted at the right time. All these were the result of the multiple role pressure on working students, which affects both their academic and social competence.

In the last few decades, scholars studying work-family conflict have accumulated ample evidence that work-family conflict is an important and pervasive phenomenon, with unfavorable consequences, such as stress (Allen 2000), job dissatisfaction (Kossek \& Ozeki, 1998), lowered performance and commitment, and turnover (Kossek \& Ozeki, 1999). As a consequence, prevention of work-family conflict is becoming an increasingly pressing problem for companies. In this work the aim is to investigate how work-family conflict and job satisfaction affect quality of work life.

\section{Hypothesis to be tested}

1. There will be a significant effect of work-family conflict on quality of work life.

2. There will be a significant effect of job satisfaction on quality of work life.

3. There will be a significant effect of sex on work family conflict, job satisfaction and quality of work life.

\section{Research design}

\section{METHODS}

A survey research using the independent group design was used for the study. This was achieved through the administration of a carefully controlled questionnaire.

\section{Participants}

The sample used in this study comprises of one hundred and eighty-nine (189) participants, ninety-one (91) from public sector and ninety-eight (98) from private sector. The sample population is made up of one hundred female (100) and eighty-nine (89) male. Workers in the public sectors including teachers, medical doctors nurses and also workers in private sector including private school teachers, medical doctors and nurses of private hospitals, They are all residents and working in Ado-Ekiti, Ekiti State. 


\section{Instruments}

Three main psychological constructs were measured using self-report instruments. Questionnaire with section A-D was administered to participants. Section A of the questionnaire contains the demographic information of the participants, questions relating to occupation- respondents were asked to specify their occupation as either working in the public sector or private sector, respondents were also asked to indicate their gender, age and educational qualification.

Section B contains an instrument used for measuring quality of work life called The Leiden Quality of Work life Scale developed by Margot and Stan (1999). The Leiden Quality of Work Life Scale was constructed to assess work characteristics from two influential occupational stress models, the Job Demand Control Support model (Johnson \& Hall, 1988; Johnson, 1989; Karasek \& Theorell, 1990) and the Michigan model (Caplan, Cobb, French, Van Harrison \& Pinneau, 1975). It measures 12 work characteristics, namely, skill discretion, decision authority, task control, work and time pressure, role ambiguity, physical exertion, hazardous exposure, job insecurity, lack of meaningfulness, social support from supervisor and social support from coworkers and the outcome variable of job satisfaction.

The correlations between the scales indicated that some scales were very strongly related to one another. The results of the confirmatory factor analysis, however, and the different correlations of the control concepts with the other work characteristics, gave good reason to view them as separate, though related concepts. The equal between factor correlations was 87 to .88. The validity of the questionnaire can thus be seen as satisfactory. The internal reliability of the scales was assessed by means of Cronbach alpha. The model includes 59 items, measuring 12 factors. Although the Goodness of Fit Index (GFI) and the Non normed Fit Index (NNFI) were still somewhat below the recommended criterion (.90), the RMSEA indicates a good fit of the model. The alpha coefficient of QWL as measured by the LQWLQ was .86.

Section C contains an instrument for measuring work and family conflict called Work Family Conflict Scale (WFC). It was designed by Netemeyer, Boles and McMurrian (1996) to measure the relationship between work and family conflict and family and work conflict among individuals in working population. In terms of reliability, Chung et al. (2004) reported coefficient alphas ranging from .87 to .91 for country of origin subscale and .76 to .81 for European American subscale. Test-retest reliability for the two subscales were reported to be .89 and .78 respectively. Reliability data for the domain subscales ranged from .76 to .87 for language, .65 to .71 for food consumption, .67 to .89 for cultural knowledge, and .74 to .79 for cultural identity for the acculturation and enculturation measures. According to Netemeyer et al. (1996), the internal consistencies of both scales are adequate, with alpha estimates ranging from .83 to .89 , and an average alpha of .88 for WFC, and of .86 for FWC).

Section D contains job satisfaction scale which was used for measuring the level of satisfaction an individual has as regards to his job. The Generic Job Satisfaction Scale was designed by Scott MacDonald and Peter Maclntyre (1997) to measure job satisfaction. The Chronbach's alpha reliability for this scale is $(\alpha=.77)$. The diversity of item themes likely reduced the reliability coefficient. However, a diversity of items is consistent with the intent to include the relevant facets of job satisfaction of what was been measured.

A t-test revealed no significant difference between males and females. A one way ANOVA revealed no significant differences between different occupational groups. However, a significant effect was found for age group $(\mathrm{p}<.001)$. Correlations were computed between the scale scores and variables representing characteristics of the job and measures of workplace affect. All items of the scale were above the traditional cut-off value of .30, the job satisfaction 
scale was significantly correlated with variables measuring factors outside the workplace, correlations were also computed with variables representing affective reactions to life in general such that the highest correlation was observed between job satisfaction and perhaps the most general measure of general measure of affectively, "I feel happy" (r2 =.37). These results coupled with those observed for variables within the workplace, support the validity of the scale and demonstrate the potentially pervasive effects of satisfaction with one's job.

\section{Procedure for data collection}

The subjects were selected and administered questionnaires at their various workplace, because there was no special place set aside for this purpose, the difficult items were discussed with the respondents and they were also informed that the data is for research purpose. Two hundred subjects participated in the study while one hundred and eighty-nine was found valid for analysis.

\section{Method of data analysis}

Four hypotheses were tested in this study. Independent t-test was used in analyzing the hypotheses.

\section{RESULTS}

Hypothesis one which states that there will be a significant effect of work-family conflict on quality of work life was tested using the independent t-test. The result is presented in the table below.

Table 4.1: independent t-test table showing the effect of work-family conflict on quality of work life.

\begin{tabular}{|l|l|l|l|l|l|r|l|}
\hline Variable & Level & $\mathrm{N}$ & Mean & SD & Df & t & P \\
\hline \multirow{2}{*}{ Work Family Conflict } & High & 102 & 26.48 & 4.97 & \multirow{2}{*}{187} & \multirow{2}{*}{4.37} & $<0.05$ \\
\cline { 2 - 6 } & Low & 87 & 38.07 & 3.58 & & & \\
\hline
\end{tabular}

From Table 4.1above, the result shows that there is a significant effect of work family conflict on quality of work life $t(187)=4.37, \mathrm{p}<.05$. A closer look at the mean score reveals that employee with higher experience of work family conflict have lower level of quality of work life as compared to employees with lower experience of work family conflict.

Hypothesis two which states that there will be a significant effect of job satisfaction on quality of work life was tested using the independent t-test. The result is presented in the table below.

Table 4.2: independent t-test table showing the effect of job satisfaction on quality of work life.

\begin{tabular}{|l|l|l|l|l|l|c|l|}
\hline Variable & Level & $\mathrm{N}$ & Mean & SD & Df & t & P \\
\hline \multirow{3}{*}{ Job satisfaction } & High & 76 & 35.97 & 6.58 & \multirow{2}{*}{187} & 7.67 & $<0.05$ \\
& & & & & & & \\
\cline { 2 - 8 } & Low & 113 & 163.07 & 4.58 & & & \\
\hline
\end{tabular}

From Table 4.2 above, the result shows that there is a significant effect of job satisfaction on quality of work life $t(187)=7.67, p<.05$. A closer look at the mean score reveals that employee with higher experience of job satisfaction have higher level of quality of work life as compared to employees with lower experience of job satisfaction. 
Hypothesis three which states that there will be a significant effect of sex on work family conflict, job satisfaction and quality of work life was tested using the independent t-test. The result is presented in the table below.

Table 4.3: independent t-test table showing the effect of sex on work family conflict, job satisfaction and quality of work life.

\begin{tabular}{|l|l|l|l|l|l|l|l|}
\hline Variable & Gender & $\mathrm{N}$ & Mean & SD & Df & t & P \\
\hline Work family & Male & 89 & 25.99 & 9.17 & 187 & 0.19 & $>.05$ \\
conflict & Female & 100 & 26.90 & 8.86 & & & \\
\hline Quality of work & Male & 89 & 161.46 & 32.29 & 187 & 0.82 & $>.05$ \\
life & Female & 100 & 164.75 & 22.69 & & & \\
\hline Job satisfaction & Male & 89 & 35.98 & 9.20 & 187 & 0.04 & $>.05$ \\
& Female & 100 & 35.92 & 10.00 & & & \\
\hline
\end{tabular}

From Table 4.3 above, the results shows that there are no significant sex differences in the perception of work-family conflict $t(187)=0.19 p>.05$, quality of work life $t(187)=0.82 p>.05$ and job satisfaction $t(187)=0.04 \mathrm{p}>.05$. The hypothesis is therefore rejected. This implies that there is no significant effect of gender on work family conflict, job satisfaction and quality of work life.

\section{DISCUSSION}

Hypothesis one which states that there will be a significant effect of work-family conflict on quality of work life was tested using independent t-test. The results show there is a significant effect of work-family conflict on quality of work life. The hypothesis is therefore confirmed. The result reveals that employees with higher experience of work-family conflict have poor quality of work life. This finding corroborates previous researches on quality of work life.

In a study conducted by Loscocco and Roschelle (1991), they observed that work-related stress and balancing work and non-work life domains affects quality of work life significantly and should be conceptually considered as determinants of quality of working life. In line with the suggestion by Herriot (1992) that many a time's people find themselves in conflict between family life and work and what actually they perceive as success in life as compared to what success they get. Family and work are two most important domains of life and a balance is crucial. It is observed that because of the conflicting role demands between job and family, and commitment, QWL is inversely proportional to the work conflict, meaning that the higher the work role conflict, the lower will be the quality of family life, and vice versa. Difficulties in meeting demands from the two settings work-family conflict, might be due to the amount of time spend at work (Åkerstedt, Ingre, \& Eriksen, 2003; Van Rijswijk, Bekker, Rutte, \& Croon, 2004) or a result traditional sex roles (Lindfors, Berntsson, \& Lundberg, 2006).

Hypothesis two which states that there will be a significant effect of job satisfaction on quality of work life was tested using independent t-test. The result shows that there is a significance effect of job satisfaction on quality of work life. A study conducted by Cohen, Kinnevy \& Ditcher (2007) shows that job satisfaction is one of the variables in work and is seen as an indicator of quality of work life. Warr \& colleagues (1979 in their survey of quality of working life, considered a variety of factors resulting in quality of work life, including work involvement, perceived intrinsic job characteristics, job satisfaction, life satisfaction and intrinsic job motivation. They studied different correlations in their research among factors that results to quality of work life and a conclusion was made that there exists a moderate association between total job satisfaction and total life satisfaction and happiness on quality of work life. In a research conducted by Baba \& Jamal (1991), he suggested a list of the determinants of quality of working life that includes job satisfaction and work-family conflicts among others. According to Danna \& Griffin (1999), Quality of Working Life is a holistic concept, which not only 
considers work-based factors such as job satisfaction, satisfaction with pay and relationships with work colleagues, but also includes factors that predict life satisfaction and general feelings of well-being

Hypothesis three which states that there will be a significant sex differences on work family conflict, job satisfaction and quality of work life using independent t-test. The result shows there is no significant effect of gender on work family conflict, job satisfaction and quality of work life.

Given that more and more women are entering the workforce, it has become imperative to understand how men and women might differ in their job attitudes. This research study tries to observe if gender had any significant effect on work family conflict, job satisfaction and quality of work life. Research report by Bellavia and Frone (2005) showed that men report higher but not statistically significant level of interference than women in two national surveys, while some other researchers found significantly lower level of interference (Grzywacz, Almeida, \& McDonald, 2002; Mennino, Rubin, \& Brayfield, 2005; Winslow, 2005). Further studies showed that WIF occurred more than FIW among male employees due to commitment to work responsibilities in relation to family responsibilities (Eby, et al., 2005; Geurts, Taris, Kompier, Dikkers, van Hooff, \& Kinnunen, 2005). Just as studies from Berntsson, Lundberg and Krantz (2006) disclosed that men focused mainly on their work role, which seemed to be fairly resistant to feelings related to conflicting demands. Although, women are not fully exempted with this type of conflict, they however continue to spend more time on childcare and housework, while men have generally increased their contributions and reduced the gap with women as FIW is conversely more related to well-being (Bianchi, Robinson, \& Milkie, 2006).Given the openness of the economy, political changes, changes in societal values, the balance of job and family obligation has shifted dramatically. According to Frone and Rice (1987), the shifts in family and work domains, individuals must face and adapt to the inter-role conflict. Researches in this regard have been consistent, different researchers' reports different views on the issue of gender as either having effect or not. A study conducted by Alavi \& Askaripur (2003) amongst 310 employees in government organization found no significant effect in job satisfaction among male and female employees. A possible explanation is offered by Tolbert \& Moen (1998), who maintains that men and women attach value to different aspects of the job. This therefore makes it a bit difficult to measure difference of gender in work-family conflict, job satisfaction and quality of work life.

\section{REFERENCES}

Aamodt, M.G. (2004). Applied Industrial/Organisational Psychology (4th ed). USA: Thompson/Wadsworth.

Alavi, H.R., \& Askaripur, M.R. (2003). The relationship between self-esteem and job satisfaction of personnel in government organisations. Public Personnel Management 32 (4): 591-599.

Aryee, S., Luk, V., Leung, A., \& Lo, S. (1999). Role stressor, inter-role conflict andwell-being: The moderating influence of spousal support and copying behaviour among employed parents in Hong Kong.

Atchison, T. (1999). They myths of employee satisfaction.Healthcare Executive 14 (2):18-23.

Bajpai, N., \& Srivastava, D. (2004). Sectorial comparison of factors influencing job satisfaction in Indian banking sector. Singapore Management Review 26 (2): 89-99.

Berkowitz, L. (1987). Pay, equity, job gratifications and comparisons in pay satisfaction. Journal of Applied Psychology 72 (4): 544-551.

Chandranshu, S. (2012). Factors affecting quality of work life: empirical evidence from India organisations. Australian Journal of Buisiness and Management Research. Vol 1, No 11, 31-40 
Chan, K.W. and Wyatt, T.A. (2007). Quality of Work Life: A Study of Employees in Shanghai, China, Asia Pacific Business Review, Vol. 13, No. 4, pp 501-517.

Connolly, K., \& Myers, E. (2003). Wellness and mattering: the role of holistic factors in job satisfaction. Journal of Employment Counselling 40 (4): 287-295.

Chan, K.W. And Wyatt, T.A. (2007), Quality of Work Life: A Study of Employees in Shanghai, China, Asia Pacific Business Review, Vol. 13, No. 4, pp 501-517.

Feldman, D. (2000). The Dilbert syndrome: How employee cynicism about ineffective management is changing the nature of careers in organizations. American Behavioral Scientist, 43, 1286-1301.

Friday, S., \& Friday, E. (2003). Racio-ethnic perceptions of job characteristics and job satisfaction. Journal of Management Development 22 (5): 426 - 442.

Frone M.R, \& Rice, R.W. (1987). Work-family conflict: The effect of job and family involvement. Journal of Vocational Behaviour 8: 45-53.

Frone, M.R., Russell, M., \& Cooper, M.L. (1992). Antecedents and outcomes of work-family conflict: A model of the work- family interface. Journal of Applied Psychology, 77, 65-78.)

Glass, J. L., \& Finley, A. (2002). Coverage and effectiveness of family-responsive workplace policies. Human Resource Management Review, 12, 313-337.

Greenh aus, J. H., \& Beutell, N. J. (1985). Sources of conflict between work and family roles. Academy of Management Review, 10, 76-88.

Greenhaus, J.H., \& Powell, G. (2006). When work and family are allies: A theory of work family enrichment. Academy of Management Review, 31(1), 72-92.

Hackman, J.R. \& Oldham,R.G. (1980), Work Redesign, Reading, M.A: Addison-Wesley

Halbesleben, J. R. B. (2006). Sources of social support and burnout: A meta-analytic test of the conservation of resources model. Journal of Applied Psychology, 91(5), 1134-1145.

Herzberg, F., Mausner, B., and Snyderman, B. B. 1967 The Motivation to Work (2ND ED.). New York: Wiley.

Hill, E. J., Ferris, M., \& Martinson, V. (2003). Does it matter where you work? A comparison of how three work venues infl uence aspects of work and personal/family life. Journal of Vocational Behaviour, 62, 220-241

Ichniowski, Casey, Thomas A. Kochan, David Levine, Craig Olson and George Strauss. 1996. "What Works at Work: Overview and Assessment." Industrial Relations 35(3): $\quad$ 299-333.

Johns, G. (1996). Organisational behaviour: Understanding and managing life at work (4thed.). Harper Collins College Publishers.

Kacmar, K., \& Ferris, G. (1989). Theoretical and methodological considerations in the age-job satisfaction relationship. Journal of Applied Psychology 74 (2): 201-207.

Kinnunen, U., \& Mauno, S. (1998). Antecedents and outcomes of work-family conflict among employed women and men in Finland. Human Relations 52, 157- 177.

Kossek, E. E., \& Ozeki, C. (1998). Work-family conflict, policies, and the job-life satisfaction relationship: A review and directions for organizational behaviour-human resources research. Journal of Applied Psychology, 83, 139149.

Lambert, E.G., Hogan, N.L., Barton, A., \& Lubbock, S.M. (2001). The impact of job satisfaction on turnover intent; A test of a structural measurement model using a national sample of workers. Social Science Journal 38 (2): 233251.

Loscocco, K.A. (1990). Reactions to blue-collar work: A comparison of women and men. Work \& Occupations 17 (2): $152-178$.

Luthans, F. (1995). Organisational behaviour. (7th ed.). McGraw-Hill, Inc.

Margot, V. D. And Stan, M. (1999). The Leiden quality of work questionnaire: its construction, factor structure and psychometrics qualities. Psychological Reports, Vol 85, pp 954- 962

Miles, E.W., Patrick, S.L., \& King, W.C. (1996). Job level as a systematic variable in predicting the relationship between supervisory communication and job satisfaction. Journal of Occupational and Organisational Psychology 69 (3): 277-293. 
Benjamin, O. A. (2015). Effect of Work-Family Conflict and Job Satisfaction on Quality of Work Life. Advances in Social Sciences Research Journal, 2(2) $51-60$.

Moses, B. (1999). Career planning mirrors social change. The Globe and Mail [On-Line]. Retrieved January 18, 2001 from the World Wide Web: http://www.bbmcareerdev.com/careerplan.html

Mowday, R., Porter, L., \& Steers, R. (1982). Employee-organisations linkages - The psychology of commitment, absenteeism and turnover. LONDON: Academic Press

Netemeyer, R. G., Boles, J. S., \& McMurrian, R. (1996). Development and validation of work-family conflict and family-work conflict scales. Journal of Applied Psychology, 81(4), 400-410.

O’Herron, P., \& Simonsen, P. (1995). Career development gets a charge at Sears Credit. Personnel Journal, 74 (5), 103-106.

Okpara, J.O. (2004). Personal characteristics as predictors of job satisfaction: An exploratory study of IT managers in a developing economy. Information Technology and People 17 (3): 327-338.

Oshagbemi, T. (1997). The influence of rank on the job satisfaction of organisational members. Journal of Managerial Psychology 12 (7): 511-520.

Owens, P. L. 2006. One more reason not to cut your training budget: The relationship between training and organizational outcomes. Public Personnel Management, 35(2): 163-171.

Robbins, S.P. (1989). Organisational behaviour: Concepts, controversies and applications. (4th ed.). New JERSEY: Prentice Hall.

Rhoades, L and Eisenberger, R. 2002. Perceived Organizational Support: A Review of the Literature, Journal of Applied Psychology, Volume 87, Issue 4, August 2002, Pages 698-714

Saal, F., \& Knight, P. (1988). Industrial/Organisation Psychology-Science and Practice CALIFORNIA: Brooks/Cole Publishing Company.

Sinha, P \& Sayeed O.B. (1980), “Measuring Quality of Working Life: Development of an Inventory”, Indian Journal of Social Work, 41: 219-26.

Srivastava, A.K. (2007), Perceived Work Environment and Employees' Health, Psychological Studies, Vol. 52, No. 4, pp 345-347.

Thompson, C. A., \& Prottas, D. J. (2006).Relationships among organizational family support, job autonomy, perceived control, and employee well-being. Journal of Occupational Health Psychology, 10(4), 100-118.

Tolbert, P.S., \& Moen, P. (1998). Men's and women's definitions of “good” jobs. WORK \& Occupations 25 (20): 168195.

Van Daalen, G., Willemsen, T. M., \& Sanders, K. (2006). Reducing work-family conflict through different sources of social support. Journal of Vocational Behavior, 69, 462- 476.

Voydanoff, P. (1988). Work role characteristics family structure demands and work family conflict. Journal of Marriage and the Family 50: 749-761.

Walton, R.E (1975). Criteria for quality of work life. In Davis, L.E and Cherns, A.B. (eds.). The quality of working life. Volume 1: Problems, Prospects and the state of the art. New York: The Free Press.

Wanous, J .P. Reichers, A. E and Austin, J. T., 2000, “Cynicism about organizational change: Measurements, antecedents and correlates," Group \& Organization Management 25, 132-153

Welsh, J.A., \& Bierman, K.L. (2002). Social competence. Gale Encyclopaedia of Childhood and Adolescence. 